\title{
Profile of opportunistic infections in AIDS patients in relation to CD4 count in a tertiary care hospital
}

\author{
AR Gnananjali, MN Sumana* \\ From 2nd International Science Symposium on HIV and Infectious Diseases (HIV SCIENCE 2014) \\ Chennai, India. 30 January - 1 February 2014
}

\section{Background}

HIV/AIDS is a global pandemic with cases reported from virtually every country. The CD4 cells are the primary target cells for HIV. The hallmark of HIV disease is a profound immunodeficiency resulting from a progressive quantitative and qualitative deficiency of CD4+ $\mathrm{T}$ cells. As CD4 count decreases, opportunistic infections (OIs) manifest. HIV infection progressing to AIDS is associated with many OIs.

\section{Methods}

One hundred seropositive HIV patients were selected, depending upon clinical presentation and physical examination, appropriate laboratory diagnostic methods were employed for detection of OIs. CD4 count was done by FACS. The occurrence of various OIs and CD4 counts were correlated.

\section{Results}

This study involved a descriptive study and tuberculosis (43.9\%) was found to be most common OI seen in patients with mean CD4 count $360 \pm 56$ cells $/ \mu \mathrm{L}$, followed by candidiasis (14.6\%) with mean CD4 count $324 \pm 42$ cells $/ \mu \mathrm{L}$, diarrhea due to coccidian parasite infection (8.5\%) with mean CD4 count $97 \pm 15$ cells/ $\mu \mathrm{L}$, cryptococcal meningitis (3.65 \%) and Pneumocystis jiroveci pneumonia (3.65 \%) with mean CD4 count $92 \pm 6$ cells/ $\mu \mathrm{L}$. CD 4 count of 20 patients were followed up 6 months after initiating ART and it was observed that CD4 count in 16 patients had increased.

\section{Conclusion}

Tuberculosis and candidiasis was seen in patients with CD4 count above 300 cells/ $\mu \mathrm{L}$. Diarrhea due to coccidian parasites, cryptococcal meningitis and PCP was seen in patients with CD4 count below 100cells/ $\mu \mathrm{L}$. OIs cause substantial morbidity and hospitalization, and shortens survival of HIV infected patients.

Published: 27 May 2014

doi:10.1186/1471-2334-14-S3-P75

Cite this article as: Gnananjali and Sumana: Profile of opportunistic infections in AIDS patients in relation to CD4 count in a tertiary care hospital. BMC Infectious Diseases 2014 14(Suppl 3):P75.

* Correspondence: mnsumana12@gmail.com

Department of Microbiology, JSS Medical College, Mysore, Karnataka, India

Submit your next manuscript to BioMed Central and take full advantage of:

- Convenient online submission

- Thorough peer review

- No space constraints or color figure charges

- Immediate publication on acceptance

- Inclusion in PubMed, CAS, Scopus and Google Scholar

- Research which is freely available for redistribution
() Biomed Central 